Article

\title{
Effect of an Essential Oil Blend on Dairy Cow Performance during Treatment and Post-Treatment Periods
}

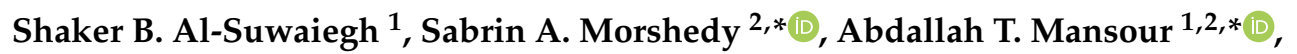 \\ Mohamed H. Ahmed ${ }^{2}$, Soliman M. Zahran ${ }^{2}$, Tareq M. Alnemr ${ }^{3}$ and Sobhy M.A. Sallam ${ }^{4}$ \\ 1 Animal and Fish Production Department, College of Agricultural and Food Sciences, King Faisal University, \\ P.O. Box 420, Al-Ahsa 31982, Saudi Arabia; shaker@kfu.edu.sa \\ 2 Department of Animal and Fish Production, Faculty of Agriculture (Saba Basha), University of Alexandria, \\ Alexandria 21531, Egypt; drmhassan2008@gmail.com (M.H.A.); nonasoliman0@gmail.com (S.M.Z.) \\ 3 Department of Food and Nutrition Sciences, College of Agricultural and Food Sciences, King Faisal \\ University, P.O. Box 420, Al-Ahsa 31982, Saudi Arabia; talnemr@kfu.edu.sa \\ 4 Department of Animal and Fish Production, Faculty of Agriculture (El-Shatby), University of Alexandria, \\ Alexandria 21545, Egypt; s_sallam@yahoo.com \\ * Correspondence: sabrin_morshedy@alexu.edu.eg (S.A.M.); amansour@kfu.edu.sa (A.T.M.)
}

Received: 24 August 2020; Accepted: 29 October 2020; Published: 2 November 2020

check for updates

\begin{abstract}
Essential oils (EOs) and their active components are attracting a lot of attention as sustainable feed additives due to their known antimicrobial properties against a variety of microorganisms, including bacteria, protozoa, and fungi. They also have biological therapeutic, antioxidant, and flavor properties. They can be used for modifying the rumen environment and improving animal productivity. The present study was designed to investigate the effect of supplementation with 2.5 and $5 \mathrm{~g} / \mathrm{head} / \mathrm{day}$ of an essential oils blend (EOB) of clove, oregano, and juniper in equal proportions on milk production and quality, and physiological status of early lactating Holstein dairy cows for 8 weeks of treatment followed by 8 weeks of posttreatment. The results revealed an improvement in milk yield $(p \leq 0.02)$ and feed efficiency $(p \leq 0.001)$ with EOB at a dose of $2.5 \mathrm{~g} / \mathrm{head} / \mathrm{day}$. The percentages of milk protein and lactose were increased $(p \leq 0.03)$ with a high dose of EOB inclusion during the treatment period as compared with the control group. Milk fat percentage, fat-corrected milk, and energy-corrected milk were not significantly affected by EOB supplementation. The supplementation of EOB tended to decrease milk total bacterial and somatic cell counts when compared to the control group. The supplementation of EOB at both doses increased serum total protein $(p \leq 0.02)$ and globulin $(p \leq 0.05)$, and decreased cholesterol level $(p \leq 0.001)$ and creatinine $(p \leq 0.001)$ as compared to the control group. Furthermore, the results show that the low dose of EOB had more desirable effects on milk yield, milk total bacterial count, milk somatic cell count, and feed efficiency than the high dose, suggesting that lower doses may not inhibit rumen microbial populations. Moreover, the low doses of EOB could be used as sustainable natural alternatives to antibiotics in livestock diets.
\end{abstract}

Keywords: essential oil blend; milk production; milk constituents; feed efficiency; alternative feed additives; dairy cows

\section{Introduction}

Modifying the rumen environment to improve animal productivity has been a major focus in ruminant nutrition for several decades. Antibiotic and ionophores have been used to manipulate rumen microbial populations and improve animal productivity and health since their discovery in the 1970s [1]. Nevertheless, the use of antibiotics as feed additives in dairy cow diets is banned in the 
European Union due to the potential of residual appearance in milk and animal-derived foods [2], and the possible rise of antibiotic-resistant bacteria, which would be of great risk to human health [3].

There is a greater interest in using natural feed additives as sustainable feed additives, including probiotics [4], organic acids [5], exogenous enzymes [6], propolis [7], and plant secondary compounds [8,9]. These compounds could be used instead of antibiotics to change ruminal fermentation and enhance feed efficiency in ruminants [10]. The plant secondary compounds are classified as saponins, tannins, and essential oils (EOs) [11]. Essential oils are natural volatile components that occur in any organ of plants, including roots, stems, leaves, flowers, and fruits [9], which can be extracted by steam distillation [12]. Structurally, EOs are divided into two groups, namely terpenoids (monoterpenoids and sesquiterpenoids) and phenylpropanoids [11]. They contain a mixture of compounds, including acids, alcohols, aldehydes, acyclic esters or lactones, and nitrogen- and sulfur-containing compounds [13]. The concentration of active components in EOs can vary widely depending on the cultivar, growing conditions, or processing methods for EO extraction [14].

Essential oils and their active components are attracting a lot of attention due to their known antimicrobial properties against a variety of microorganisms, including bacteria, protozoa, and fungi [9]. They also have biological therapeutic, antioxidant, and flavor properties [11]. In particular, clove (Syzygium aromaticum) EO has been used anciently as a flavoring agent and antimicrobial material in food. It is also used as an antiseptic in oral infections anesthetic, a topical application to alleviate pain and to boost healing [15]. Lately, it has proven its antifungal and antibacterial activities against a wide range of gram-positive and gram-negative bacteria, insecticidal, anticarcinogenic, and antioxidant properties $[15,16]$. The main components of clove EO are eugenol $(78.72 \%), \beta$-caryophyllene $(8.82 \%)$ and eugenyl acetate (8.74\%) [17]. Eugenol is a phenylpropanoid compound with a phenolic structure [11] and is primarily responsible for a wide range of pharmacological and biological properties of clove EO [15].

Moreover, oregano (Origanum spp.) EO contains large and variable quantities of carvacrol and thymol, which constitute about 78 to $82 \%$ of the total oil [18-20]. Carvacrol is a naturally occurring isomer of thymol [21], and both are monoterpenoids and phenolic compounds. The other constituents of oregano EO are monoterpene hydrocarbons (5 to 7\%) including $\gamma$-terpinene and p-cymene [20]. Oregano EO has strong biological activities including antimicrobial activity against a wide range of gram-positive and gram-negative bacteria, anti-inflammatory, and antioxidation [18,22].

Additionally, juniper berry (Juniperus oxycedrus) EO is largely comprised of monoterpenoid hydrocarbons $(66.2-74.8 \%)$, such as $\alpha$-pinene $(51.4 \%)$, myrcene $(8.3 \%)$, sabinene $(5.8 \%)$, limonene $(5.1 \%)$, and $\beta$-pinene (5.0\%) [23]. Moreover, the second major component group of juniper berries EO is sesquiterpenes (16.8-17.3\%) [24]. Juniper berries EO and their extracts were traditionally used for medicinal and flavoring purposes and have wide applications in pharmaceuticals, perfumery, aromatherapy, and food preparations [25]. Juniper berries EO has strong antioxidant properties, whereas its antioxidant activity is attributable to electron transfer [23]. Juniper berries EO has diuretic, antiseptic, antimicrobial, and antiradical properties [26].

From the previous studies, the combinations of EOs could have additive, synergistic, or antagonistic effects on the productivity of ruminants [27-31]. This interaction among EO components may cause positive changes in ruminal fermentation [32-34] but the combination that will cause this success is still unknown [27]. The effects of dietary EOs or their combinations on the performance of dairy cattle were variably with conflicting results. Few studies reported that feed intake was increased with the inclusion of EOB [35]. However, other research stated that the inclusion of EOB either decreased [36] or did not affect feed intake [37,38]. Additionally, the effects of EOB on milk yield and composition are even conflicting. Several studies reported that milk yield and composition were not affected by the addition of EOB in lactating cows [39]. However, other studies showed that milk yield and composition were increased by the addition of EOB in lactating cows [40] and lactating ewes [41].

To our knowledge, the effect of clove, oregano, and juniper EOs combination on productive performance of lactating dairy Holstein cows has not been investigated before. Therefore, 
this experiment was conducted to evaluate the effects of clove, oregano, and juniper EOs combination with different levels on milk production, composition and quality, dry matter intake, feed efficiency, and hemato-biochemical parameters of early lactating dairy Holstein cows.

\section{Materials and Methods}

\subsection{Experimental Animals and Management}

A total of 33 healthy and parasite-free Holstein dairy cows ( $477 \pm 13.3 \mathrm{~kg}$ live body weight; BW) at early lactation ( 2 weeks after parturition) were grouped according to the parity and productivity in a randomized complete block design. According to parity, each group included 6 heifers in their first calving stage and 5 multiparous cows $(2.87 \pm 0.17)$. According to productivity, the heifers were classified based on milk production $(21.92 \pm 0.95 \mathrm{~kg} /$ day $)$ in the first 2 weeks after calving. Moreover, the milk yield of cows $(23.06 \pm 1.22 \mathrm{~kg} /$ day $)$ in the last lactation season was considered in the experimental design (allocation of the cows in each group).

The cows were housed in semishaded barns with subdivision. The cows were individually distributed into 3 equal groups. The first group was the control (without EOB supplementation); the second group was classified as the $\mathrm{EOB}_{2.5}$ group, which received $\mathrm{EOB}$ at a dose of $2.5 \mathrm{~g} / \mathrm{head} / \mathrm{day}$; and the third group was classified as $\mathrm{EOB}_{5.0}$, which received $\mathrm{EOB}$ at a dose of $5.0 \mathrm{~g} / \mathrm{head} /$ day. The selected doses were applied according to our previous work [42] and literature $[43,44]$.

In this study, the investigated EOB was prepared in the laboratory by mixing equal proportions of clove (S. aromaticum), oregano (O. majorana), and juniper (J. oxycedrus) EOs. The individual dose of EOB was mixed daily in the concentrate mixture immediately before the morning feeding. These EOs were procured by El Captain, Company (Cap Pharm) for Extracting Natural Oils, Plants, and Cosmetics; El Obour City, Cairo, Egypt. The study started at 2 weeks after calving as adaptation period and the experiment lasted for 16 weeks, which was divided into 2 periods as follows: 8 weeks as the treatment period (with EOB supplementation) and 8 weeks as the post-treatment period (without EOB supplementation) to investigate an extended effect of EOB supplementation after stopping treatment.

The feeding experiment was carried out at the Milk Production Project, Faculty of Agriculture (El-Shatby), Alexandria University, Egypt. Laboratory analyses were conducted at the Laboratories of Animal Nutrition at the Faculty of Agriculture (El-Shatby) and the Faculty of Agriculture (Saba Basha), Alexandria University, Egypt. The care and management of cows were approved by the Ethical Committee of Alexandria University [Approval No. AU: 14/20/05/11/3/09].

\subsection{Ration and Feeding Regime}

The cows were individually fed with the concentrate mixture and Egyptian green clover (Trifolium alexandrinum). The cows fed the ration ad libitum, and the feed was offered 3 times daily at 6:00, 12:00, and 18:00, and the refusals were recorded daily to determine feed intake. The concentrate mixture and Egyptian green clover were fed separately at proportions 1:2 as fed basis, respectively, with free access to fresh water. The diet was formulated to provide the nutrient requirements of early lactating dairy cows [45]. Samples of the concentrate mixture and Egyptian green clover were separately collected every 2 weeks and dried in a forced air-oven at $60{ }^{\circ} \mathrm{C}$ for $72 \mathrm{~h}$ to determine dry matter intake (DMI). The dried samples were ground by electric grinder machine (500 g, DAMAI, Zhejiang, China) to pass through a $1 \mathrm{~mm}$ screen and stored until chemical analysis for dry matter (DM, was determined by oven drying at $105^{\circ} \mathrm{C}$ for $24 \mathrm{~h}$ ), ether extract (EE), crude protein (CP), and ash, which were performed according to AOAC [46]. Neutral detergent fiber (NDF) and acid detergent fiber (ADF) were determined without using sodium sulfite or $\alpha$-amylase [47]. Lignin (sa) was determined by the solubilization of cellulose with sulfuric acid $(720 \mathrm{~mL} / \mathrm{L})$ [48]. These fiber fractions were sequentially measured using an ANKOM fiber analyzer using the same sample in ANKOM filter bags and expressed exclusive of residual ash. The concentrations of hemicellulose and cellulose were estimated as the differences between NDF and ADF, and between ADF and lignin, respectively. Nonfiber carbohydrates 
were calculated as the following: Equation $=1000-(\mathrm{NDF}+\mathrm{CP}+\mathrm{EE}+$ ash $)$, and organic matter $(\mathrm{OM})$ was calculated as the difference between DM and ash. The ingredients and chemical composition of the concentrate mixture and green Egyptian clover for lactating dairy cows are presented in (Table 1).

Table 1. Ingredients of concentrate mixture and chemical composition of concentrate mixture and green Egyptian clover fed to dairy cows.

\begin{tabular}{ccc}
\hline Ingredients of Concentrate Mixture & $\mathbf{( g / k g}$ of DM Basis) & \\
\hline Ground yellow corn & 330 & \\
Wheat bran & 300 & \\
Cottonseed meal & 280 & \\
Soybean meal & 50 & \\
Calcium carbonate & 20 & \\
Sodium chloride & 10 & \\
Di-calcium phosphate & 7 & Egyptian Clover \\
Trace minerals ${ }^{1}$ & 3 & 157.7 \\
Chemical Composition & Concentrate Mixture & 857.0 \\
(g/kg of DM Basis) & (g/kg of DM Basis) & 143.0 \\
Dry matter & 900.6 & 169.4 \\
Organic matter & 961.4 & 26.2 \\
Ash & 38.6 & 619.6 \\
Crude protein & 178.1 & 364.8 \\
Ether extract & 57.9 & 103.3 \\
Neutral detergent fiber & 601.4 & 41.8 \\
Acid detergent fiber & 167.1 & 254.8 \\
Lignin (sa) & 47.9 & 260.7 \\
Non-fiber carbohydrates & 124.0 & \\
Hemicellulose & 434.3 & \\
Cellulose & 119.1 & \\
\hline
\end{tabular}

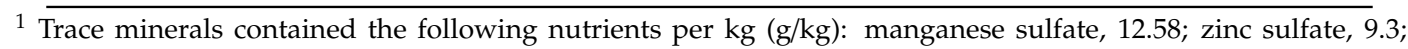
copper sulfate, 3.2; ferrous sulfate, 16.67; calcium iodate, 0.081; sodium selenite, 0.4; magnesium oxide, 9.4; cobalt sulfate, 0.2; and, sodium chloride added to kg, manufactured by Dyno Vet Company, Alexandria, Egypt. Hemicellulose $=$ neutral detergent fiber-acid detergent fiber, cellulose $=$ acid detergent fiber-lignin $(\mathrm{sa})$, nonfiber carbohydrates $=1000-$ (neutral detergent fiber + crude protein + ether extract + ash $)$.

\subsection{Milk Yield and Composition}

The cows were machine-milked 3 times daily at 5:00, 11:00, and 21:00. Milk yield (MY) for each cow was individually recorded weekly during the treatment and post-treatment periods. Feed efficiency (FE) was calculated by dividing the MY by the DMI. The samples were analyzed immediately for milk fat, protein, lactose, solids-not-fat (SNF), ash contents, and milk density by the infrared method using Milk Analyzer (Milkotester Instruments Inc., Belovo, Bulgaria).

Fat-corrected milk (FCM; $4 \%$ ) was calculated based on $4 \%$ fat using the following equation [49]:

$$
\mathrm{FCM}(\mathrm{kg} / \text { day })=(0.4 \times \mathrm{MY})+(15.0 \times \text { fat yield })
$$

Moreover, energy-corrected milk (ECM) was computed based on $3.5 \%$ fat and $3.2 \%$ protein using the following equation [50]:

$$
\operatorname{ECM}(\mathrm{kg} / \text { day })=(0.327 \times \mathrm{MY})+(12.95 \times \text { fat yield })+(7.20 \times \text { protein yield })
$$

\subsection{Milk Total Bacterial Acount}

The milk total bacterial count (TBC) was measured every 4 weeks at the treatment and post-treatment periods. Raw milk samples $(25 \mathrm{~mL}$ from each cow) were aseptically collected in the morning using a sterile screwed test tube. The collected samples were kept in an icebox and then processed immediately after delivery to the laboratory. The milk TBC was accomplished by the standard plate count [51]. A milk sample from each cow was diluted in sterilized saline with ratios ranging from $10^{-1}$ to $10^{-5}$. Then, the diluted milk samples were incubated using sterilized nutrient agar media (CM 0003 nutrient agar, OXOID Ltd., Basingstoke, Hampshire, UK) at $32{ }^{\circ} \mathrm{C}$ for $48 \mathrm{~h}$. 
The colonies of bacteria were recorded, and the plates with colonies that were lower than 30 and higher than 300 (contaminated plates) were excluded. The number of colonies counted on the Petri dishes was multiplied by the reciprocal of the proper dilution rate to obtain milk TBC.

\subsection{Milk Somatic Cell Count}

The milk somatic cell count (SCC) was measured every 2 weeks of the treatment period and every 4 weeks of the post-treatment period using Ekomilk SCAN Somatic Celbothyzer (Bulteh 2000 Ltd., Stara Zagora, Bulgaria).

\subsection{Hematological and Serum Biochemical Parameters}

Blood samples were collected via venipuncture procedure using evacuated tubes from the tail of experimental cows every 2 weeks at the treatment and post-treatment periods. The blood samples were divided into 2 proportions. The first part contained an anticoagulant (Ethylenediaminotetraacetate, EDTA coated vacuum tube) and used for hematological assay. In brief, the red blood cells count (RBCs) was manually counted using a standard Neubauer cell counting chamber after diluting blood samples 200 times with a diluting fluid (10\% sodium sulphate, $2 \%$ sodium chloride and mercuric chloride $1 \%$ solution). White blood cells (WBCs) were manually counted using a standard Neubauer cell counting chamber and after diluting blood samples 20 times with a diluting fluid (1.5\% glacial acetic acid solution and a few crystals of gentian violet). Hemoglobin was determined by commercial kits (Biodiagnostic Co, Cairo, Egypt).

The second part was collected without using an anticoagulant (plan vacuum tube), allowed blood to clot for $30 \mathrm{~min}$ at $25^{\circ} \mathrm{C}$, and then centrifuged at $750 \times \mathrm{g}$ for $20 \mathrm{~min}$ and the top yellow serum layer pipetted. The serum samples were stored frozen at $-20^{\circ} \mathrm{C}$ until use.

Total protein, albumin, total cholesterol, triglycerides, urea-N, creatinine, and glucose concentrations were determined in serum colorimetrically using a visible light spectrophotometer using commercial kits manufactured by Stanbio Diagnostic Company, Germany. Serum globulin value was calculated by subtracting the serum albumin value from serum total protein value.

\subsection{Statistical Analyses}

The statistical data of the experiment were analyzed as repeated measurements using the mixed procedure of SAS separately for the treatment period and the post-treatment period [52]. The data of dry matter intake, milk yield and composition, hematological, and serum biochemical parameters were statistically analyzed using the factorial model including the effects of treatment, time, and their interaction as follows:

$$
Y_{i j k}=\mu+E_{i}+T_{j}+E_{i j}+A_{k}+e_{i j k}
$$

where $\mu$ is the overall mean, $\mathrm{EO}_{\mathrm{i}}$ is a fixed effect of the $\mathrm{EO}$ concentration, $\mathrm{Tj}$ is the fixed effect of the weeks, $\mathrm{EOT}_{\mathrm{ij}}$ is the interaction between $\mathrm{EO}$ concentration and weeks, $\mathrm{A}_{\mathrm{k}}$ is a random effect of the cow in each treatment, and $\mathrm{e}_{\mathrm{ijk}}$ is the random error assumed to be independent and normally distributed with mean $=0$ and variance $=\sigma 2$.

Multiple comparisons among the means were carried out by Duncan, considering $P \leq 0.05$ as significant [53]. The nonparametric variables (TBC and SCC) were analyzed in the log transformed form.

\section{Results}

\subsection{Milk Yield and Feed Efficiency}

The results in Table 2 illustrate the effect of the supplementation with EOB (mixed equal proportions of clove, oregano, and juniper EOs) at doses of 2.5 and $5 \mathrm{~g} /$ head/day on DMI, MY, FCM, ECM, and FE ( $\mathrm{kg}$ of MY $/ \mathrm{kg}$ of DMI). The trial lasted for 8 weeks as a treatment period followed by 8 weeks as a post-treatment period (without EOB supplementation). The results showed that DMI was decreased 
( $p \leq 0.001)$ with both doses of EOB compared with the control group during the treatment period and was not affected during the post-treatment period. Additionally, the treatment with EOB had a significant effect $(p \leq 0.001)$ over the weeks for DMI during the treatment and post-treatment periods. Moreover, there was a significant interaction between weeks and treatments for DMI during the post-treatment period.

Table 2. The effect of different levels of essential oil blend supplementation on dry matter intake, milk yield, fat-corrected milk, energy-corrected milk, and feed efficiency of early lactating dairy cows $(n=11$; mean \pm SE).

\begin{tabular}{|c|c|c|c|c|c|c|c|}
\hline \multicolumn{2}{|c|}{ Items } & \multirow{2}{*}{$\begin{array}{c}\text { Control } \\
20.71 \pm 0.03^{\mathrm{a}}\end{array}$} & \multirow{2}{*}{$\begin{array}{c}\mathbf{E O B}_{2.5} \\
20.51 \pm 0.04^{\mathrm{b}}\end{array}$} & \multirow{2}{*}{$\begin{array}{c}\text { EOB }_{5.0} \\
20.50 \pm 0.04^{b}\end{array}$} & \multirow{2}{*}{\multicolumn{2}{|c|}{$\begin{array}{c}p \text { Value } \\
\mathbf{W}\end{array}$}} & \multirow{2}{*}{$\frac{\mathbf{T} \times \mathbf{W}}{0.81}$} \\
\hline & Treatment & & & & & & \\
\hline DMI (kg/day) & Post-treatment & $20.65 \pm 0.08$ & $20.76 \pm 0.07$ & $20.69 \pm 0.08$ & 0.46 & 0.001 & 0.01 \\
\hline \multirow{2}{*}{ MY (kg/day) } & Treatment & $25.76 \pm 0.31^{b}$ & $26.84 \pm 0.22^{a}$ & $26.17 \pm 0.29 \mathrm{ab}$ & 0.02 & 0.001 & 0.82 \\
\hline & Post-treatment & $23.94 \pm 0.42$ & $24.99 \pm 0.42$ & $24.71 \pm 0.44$ & 0.20 & 0.24 & 0.64 \\
\hline \multirow{2}{*}{ FCM (kg/day) } & Treatment & $24.25 \pm 0.52$ & $25.29 \pm 0.22$ & $24.87 \pm 0.28$ & 0.14 & 0.30 & 0.35 \\
\hline & Post-treatment & $22.48 \pm 0.49$ & $23.95 \pm 0.53$ & $23.53 \pm 0.64$ & 0.18 & 0.64 & 0.81 \\
\hline \multirow{2}{*}{ ECM (kg/day) } & Treatment & $25.74 \pm 0.51$ & $26.81 \pm 0.37$ & $26.32 \pm 0.40$ & 0.21 & 0.32 & 0.44 \\
\hline & Post-treatment & $23.91 \pm 0.55$ & $25.27 \pm 0.58$ & $24.93 \pm 0.69$ & 0.33 & 0.36 & 0.89 \\
\hline \multirow{2}{*}{ FE (kg milk/kg DMI) } & Treatment & $1.24 \pm 0.02^{b}$ & $1.31 \pm 0.01^{\mathrm{a}}$ & $1.28 \pm 0.01^{\mathrm{ab}}$ & 0.001 & 0.54 & 0.79 \\
\hline & Post-treatment & $1.16 \pm 0.02$ & $1.20 \pm 0.02$ & $1.19 \pm 0.02$ & 0.38 & 0.04 & 0.77 \\
\hline
\end{tabular}

Means with different superscripts within the same row are significantly different $(p<0.05)$. EOB: essential oil blend, DMI: dry matter intake, MY: milk yield, FCM: fat-corrected milk, ECM: energy-corrected milk, FE: feed efficiency, T: treatment, $\mathrm{W}$ : weeks, $\mathrm{T} \times \mathrm{W}$ : treatment $\times$ weeks. EOB; mixed equal proportions of clove, oregano, and juniper EOs, $\mathrm{EOB}_{2.5} ; 2.5 \mathrm{~g} / \mathrm{head} /$ day of $\mathrm{EOB}$, and $\mathrm{EOB}_{5.0} ; 5.0 \mathrm{~g} /$ head/day of $\mathrm{EOB}$.

The lactating dairy cows that received $\mathrm{EOB}_{2.5}$ produced more milk $(p \leq 0.02)$ by $4.3 \%$ as compared with nonsupplemented cows during the treatment period. This effect continued insignificantly during the post-treatment period. Moreover, MY was affected significantly $(p \leq 0.001)$ along the time of the treatments. Fat-corrected milk and ECM were not affected significantly by the dietary EOB supplementation in comparison with the control group during the treatment and post-treatment periods.

Feed efficiency was improved $(p \leq 0.001)$ by adding $\mathrm{EOB}_{2.5}(1.31 \mathrm{~kg} \mathrm{MY} / \mathrm{kg} \mathrm{DMI})$ as compared with the control group (1.24 $\mathrm{kg} \mathrm{MY} / \mathrm{kg}$ DMI) during the treatment period, however, no significant extended effect founded during the post-treatment period. Additionally, there was a significant difference in the interaction between treatment and weeks for FE during the post-treatment period.

\subsection{Milk Composition}

The results presented in Table 3 summarize the effects of dietary EOB supplementation on the milk composition of early lactating dairy cows. The results showed that cows fed with EOB supplementation did not affect milk fat percentage during the treatment and post-treatment periods. The percentage of milk protein was increased $(p \leq 0.03)$ with a high dose of EOB inclusion during the treatment period and insignificant during the post-treatment period as compared with the control group. The effect of weeks on milk protein percentage was significant $(p \leq 0.001)$ during the treatment period.

Table 3. The effect of different levels of essential oil blend supplementation on milk composition of early lactating dairy cows $(n=11$; mean \pm SE).

\begin{tabular}{|c|c|c|c|c|c|c|c|}
\hline \multirow{2}{*}{\multicolumn{2}{|c|}{ Items }} & \multirow{3}{*}{$\begin{array}{c}\text { Control } \\
3.60 \pm 0.06\end{array}$} & \multirow{3}{*}{$\begin{array}{c}\mathrm{EOB}_{2.5} \\
3.62 \pm 0.05\end{array}$} & \multirow{3}{*}{$\begin{array}{c}\text { EOB }_{5.0} \\
3.66 \pm 0.05\end{array}$} & \multicolumn{3}{|c|}{$p$ Value } \\
\hline & & & & & $\mathbf{T}$ & W & $\mathbf{T} \times \mathbf{W}$ \\
\hline \multirow{2}{*}{ Fat $(\%)$} & Treatment & & & & 0.39 & 0.34 & 0.25 \\
\hline & Post-treatment & $3.64 \pm 0.08$ & $3.67 \pm 0.06$ & $3.76 \pm 0.08$ & 0.53 & 0.91 & 0.99 \\
\hline \multirow{2}{*}{ Protein (\%) } & Treatment & $3.05 \pm 0.01^{b}$ & $3.06 \pm 0.01^{b}$ & $3.09 \pm 0.01^{\mathrm{a}}$ & 0.03 & 0.001 & 0.70 \\
\hline & Post-treatment & $3.06 \pm 0.02$ & $3.07 \pm 0.02$ & $3.12 \pm 0.03$ & 0.16 & 1.00 & 0.97 \\
\hline \multirow{2}{*}{ Lactose (\%) } & Treatment & $4.21 \pm 0.03^{b}$ & $4.22 \pm 0.03^{a b}$ & $4.28 \pm 0.04^{\mathrm{a}}$ & 0.03 & 0.04 & 0.51 \\
\hline & Post-treatment & $4.19 \pm 0.04$ & $4.22 \pm 0.06$ & $4.28 \pm 0.05$ & 0.51 & 0.50 & 0.97 \\
\hline
\end{tabular}


Table 3. Cont.

\begin{tabular}{|c|c|c|c|c|c|c|c|}
\hline \multicolumn{2}{|c|}{ Items } & \multirow{2}{*}{$\begin{array}{c}\text { Control } \\
7.83 \pm 0.05\end{array}$} & \multirow{2}{*}{$\begin{array}{c}\mathbf{E O B}_{2.5} \\
7.87 \pm 0.05\end{array}$} & \multirow{2}{*}{$\begin{array}{c}\text { EOB }_{5.0} \\
7.90 \pm 0.04\end{array}$} & \multicolumn{3}{|c|}{$p$ Value } \\
\hline \multirow{2}{*}{ SNF (\%) } & Treatment & & & & 0.37 & 0.32 & 0.96 \\
\hline & Post-treatment & $7.85 \pm 0.08$ & $7.91 \pm 0.06$ & $7.94 \pm 0.07$ & 0.87 & 0.18 & 0.90 \\
\hline \multirow{2}{*}{ Ash (\%) } & Treatment & $0.57 \pm 0.01^{b}$ & $0.58 \pm 0.01^{\mathrm{a}}$ & $0.60 \pm 0.01^{a}$ & 0.001 & 0.01 & 0.49 \\
\hline & Post-treatment & $0.60 \pm 0.01^{b}$ & $0.61 \pm 0.01^{\mathrm{ab}}$ & $0.63 \pm 0.01^{a}$ & 0.02 & 0.97 & 0.96 \\
\hline \multirow{2}{*}{ Density } & Treatment & $27.02 \pm 0.14$ & $27.15 \pm 0.13$ & $27.29 \pm 0.13$ & 0.36 & 0.03 & 0.95 \\
\hline & Post-treatment & $27.24 \pm 0.18$ & $27.32 \pm 0.16$ & $27.82 \pm 0.18$ & 0.06 & 0.79 & 0.37 \\
\hline
\end{tabular}

Means with different superscripts within the same row are significantly different $(p<0.05)$. EOB, essential oil blend; SNF, solids not-fat; $\mathrm{T}$, treatment; $\mathrm{W}$, weeks; $\mathrm{T} \times \mathrm{W}$, treatment $\times$ weeks. $\mathrm{EOB}$, mixing equal proportions of clove, oregano and juniper $\mathrm{EOs} ; \mathrm{EOB}_{2.5}, 2.5 \mathrm{~g} /$ head/day of $\mathrm{EOB} ; \mathrm{EOB}_{5.0}, 5.0 \mathrm{~g} / \mathrm{head} /$ day of $\mathrm{EOB}$.

The milk lactose percentage was increased $(p \leq 0.03)$ with the $\mathrm{EOB}_{5.0}$ inclusion during the treatment period and insignificantly increased during the post-treatment period. The effect of weeks on milk lactose percentage was significant $(p \leq 0.04)$ during the treatment period. Milk SNF percentage showed no significant difference with EOB inclusion during the treatment and post-treatment periods.

The milk ash percentage was increased $(p \leq 0.001,0.02)$ with the $\mathrm{EOB}_{2.5}$ and $\mathrm{EOB}_{5.0}$ inclusions during the treatment period and with $\mathrm{EOB}_{5.0}$ during the post-treatment period compared with the control group. The effect of weeks on milk ash percentage was significant $(p \leq 0.01)$ during the treatment period. The density of milk remained to be without any noticeable changes by EOB supplementation in both the treatment and post-treatment periods. However, there was a significant effect $(p \leq 0.03)$ on milk density through the weeks during the treatment period.

\subsection{Milk Total Bacterial and Somatic Cell Counts}

The effects of the dietary supplementation of two doses of EOB on milk TBC and SCC are presented in Figure 1. The milk TBC showed an insignificant reduction by 20.7 and $17.9 \%$ with $\mathrm{EOB}_{2.5}$ and $\mathrm{EOB}_{5.0}$, respectively, compared with the control group during the treatment period. This effect was expanded during the post-treatment period. Whereas there was an insignificant decrease of TBC by about 13.7 and $12.6 \%$ with $\mathrm{EOB}_{2.5}$ and $\mathrm{EOB}_{5.0}$, respectively, compared to the control group. Moreover, the weeks of the trial, as well as the interaction between time and treatment, had insignificant effects on TBC.

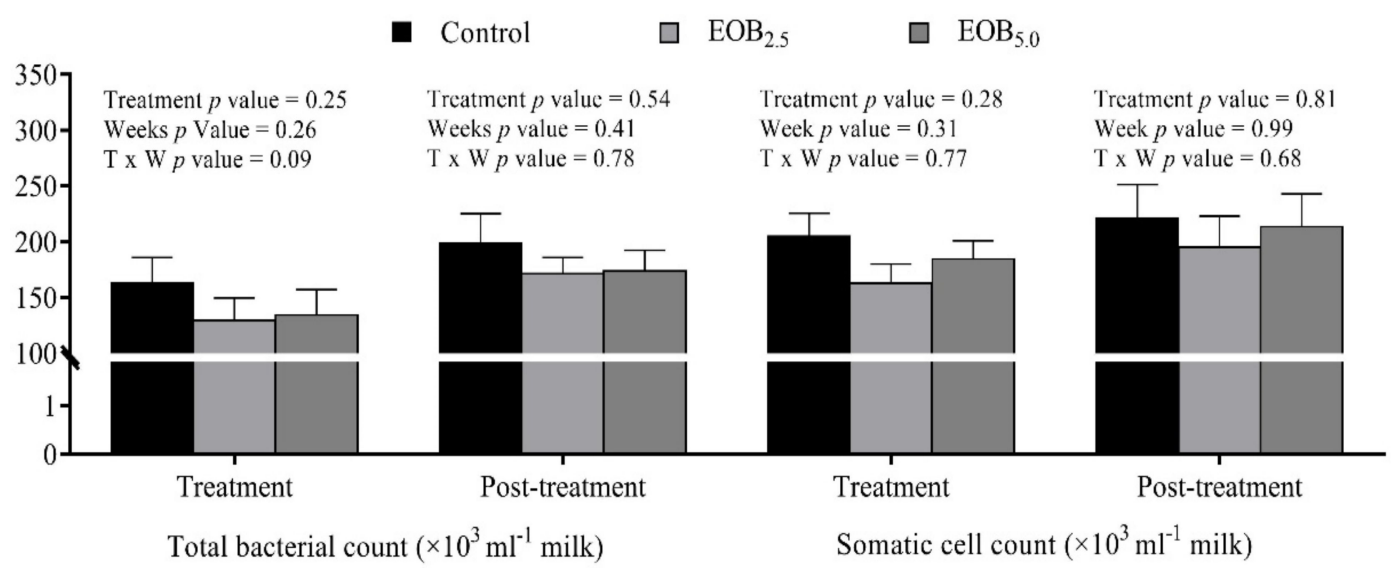

Figure 1. The effect of different levels of essential oil blend supplementation on milk total bacterial count and somatic cell count of early lactating dairy cows.

Similar trends were observed with milk SCC, where both treatments $\left(\mathrm{EOB}_{2.5}\right.$ and $\left.\mathrm{EOB}_{5.0}\right)$ caused an insignificant reduction by 20.6 and $9.9 \%$ of SCC, respectively, compared with the control group during the treatment period. Furthermore, the same trend was observed during the post-treatment period. Additionally, the effects of time, as well as the time $\times$ treatment interactions, were insignificant. 


\subsection{Hematology and Serum Biochemical Evaluation}

The hematological investigation in terms of RBCs, WBCs and $\mathrm{Hb}$ of cows fed EOB supplemented diets did not show any significant changes among groups during treatment and post-treatment periods (Table 4). There was a significant effect of time for RBCs during the post-treatment period and for WBCs during the treatment period. Additionally, there was a significant effect of time $\times$ treatment interactions for WBCs during the treatment and post-treatment periods.

Table 4. The effect of different levels of essential oil blend supplementation on red blood cells count, white blood cells count and hemoglobin of early lactating dairy cows $(n=11$; mean \pm SE).

\begin{tabular}{|c|c|c|c|c|c|c|c|}
\hline \multicolumn{2}{|l|}{ Items } & \multirow{2}{*}{$\begin{array}{c}\text { Control } \\
6.49 \pm 0.08\end{array}$} & \multirow{2}{*}{$\begin{array}{c}\mathbf{E O B}_{2.5} \\
6.48 \pm 0.08\end{array}$} & \multirow{2}{*}{$\begin{array}{c}\mathbf{E O B}_{5.0} \\
6.37 \pm 0.08\end{array}$} & \multicolumn{3}{|c|}{$p$ Value } \\
\hline \multirow{2}{*}{ RBCs $\left(\times 10^{6} / \mathrm{mm}^{3}\right.$ blood $)$} & Treatment & & & & 0.52 & 0.71 & 0.82 \\
\hline & Post-treatment & $6.63 \pm 0.11$ & $6.63 \pm 0.13$ & $6.64 \pm 0.10$ & 0.11 & 0.04 & 0.08 \\
\hline \multirow{2}{*}{ WBCs $\left(\times 10^{3} / \mathrm{mm}^{3}\right.$ blood $)$} & Treatment & $7.66 \pm 0.20$ & $7.32 \pm 0.20$ & $7.35 \pm 0.17$ & 0.39 & 0.05 & 0.00 \\
\hline & Post-treatment & $7.32 \pm 0.25$ & $7.35 \pm 0.24$ & $7.27 \pm 0.26$ & 0.43 & 0.91 & 0.03 \\
\hline \multirow{2}{*}{$\mathrm{Hb}$ value (g/dL blood) } & Treatment & $9.42 \pm 0.13$ & $9.76 \pm 0.15$ & $9.59 \pm 0.13$ & 0.66 & 0.13 & 0.52 \\
\hline & Post-treatment & $9.97 \pm 0.19$ & $10.00 \pm 0.18$ & $9.97 \pm 0.21$ & 0.47 & 0.72 & 0.86 \\
\hline
\end{tabular}

EOB, essential oil blend; RBCs, red blood cells count; WBCs, white blood cells count; $\mathrm{Hb}$, hemoglobin; $\mathrm{T}$, treatment; $\mathrm{W}$, weeks; $\mathrm{T} \times \mathrm{W}$, treatment $\times$ weeks. $\mathrm{EOB}$, mixing equal proportions of clove, oregano and juniper $\mathrm{EOs} ; \mathrm{EOB}_{2.5}, 2.5$ $\mathrm{g} /$ head/day of EOB; $\mathrm{EOB}_{5.0}, 5.0 \mathrm{~g} /$ head/day of EOB.

Meanwhile, the effects of EOB appeared in serum biochemical metabolites of treated animals (Table 5). The supplementation of EOB at both doses increased total protein $(p \leq 0.02)$ and globulin $(p \leq 0.05)$ during the treatment period and this effect continued during the post-treatment period, especially with $\mathrm{EOB}_{2.5}$ treatment. There was a significant effect of time for protein and globulin during the post-treatment period. The supplementation of $\mathrm{EOB}_{2.5}$ increased albumin $(p \leq 0.05)$ during the post-treatment period. The cholesterol levels were decreased $(p \leq 0.001)$ with both EOB supplementation treatments compared to the control group, during treatment and post-treatment periods. Further, the effects of time, as well as the time $\times$ treatment interactions were significant for cholesterol concentration during the treatment period. Triglycerides concentration was not significantly affected with treatments. The creatinine levels were decreased $(p \leq 0.001)$ with both EOB doses during the treatment period. Additionally, there were significant effects of time as well as the time $\times$ treatment interactions for creatinine level during the treatment period. Meanwhile, urea and glucose levels were not affected with EOB treatments during treatment and post-treatment periods.

Table 5. The effect of different levels of essential oil blend supplementation on serum biochemical parameters of early lactating dairy cows $(n=11$; mean $\pm \mathrm{SE})$.

\begin{tabular}{|c|c|c|c|c|c|c|c|}
\hline \multirow{2}{*}{\multicolumn{2}{|c|}{ Items }} & \multirow{3}{*}{$\begin{array}{c}\text { Control } \\
7.77 \pm 0.12^{b}\end{array}$} & \multirow{3}{*}{$\begin{array}{c}\mathbf{E O B}_{2.5} \\
8.12 \pm 0.09^{\mathrm{a}}\end{array}$} & \multirow{3}{*}{$\begin{array}{c}\mathbf{E O B}_{5.0} \\
8.11 \pm 0.08^{\mathrm{a}}\end{array}$} & \multicolumn{3}{|c|}{$p$ Value } \\
\hline & & & & & $T$ & W & $\mathbf{T} \times \mathbf{W}$ \\
\hline \multirow{2}{*}{ Total protein (g/dL) } & Treatment & & & & 0.02 & 0.57 & 0.52 \\
\hline & Post-treatment & $7.62 \pm 0.11^{b}$ & $8.04 \pm 0.16^{\mathrm{a}}$ & $7.67 \pm 0.11^{b}$ & 0.05 & 0.07 & 0.90 \\
\hline \multirow{2}{*}{ Albumin (g/dL) } & Treatment & $3.60 \pm 0.05$ & $3.64 \pm 0.06$ & $3.74 \pm 0.05$ & 0.16 & 0.48 & 0.51 \\
\hline & Post-treatment & $3.73 \pm 0.09^{\mathrm{a}}$ & $3.49 \pm 0.07^{b}$ & $3.70 \pm 0.06^{\mathrm{a}}$ & 0.05 & 0.10 & 0.57 \\
\hline \multirow{2}{*}{ Globulin (g/dL) } & Treatment & $4.18 \pm 0.12^{b}$ & $4.48 \pm 0.09^{\mathrm{a}}$ & $4.37 \pm 0.09^{\mathrm{a}}$ & 0.05 & 0.20 & 0.28 \\
\hline & Post-treatment & $3.88 \pm 0.14^{b}$ & $4.55 \pm 0.14^{\mathrm{a}}$ & $3.97 \pm 0.14^{\mathrm{b}}$ & 0.001 & 0.01 & 0.76 \\
\hline \multirow{2}{*}{ Cholesterol (mg/dL) } & Treatment & $176.77 \pm 4.96^{\mathrm{a}}$ & $150.13 \pm 2.78^{b}$ & $152.53 \pm 4.83^{b}$ & 0.001 & 0.001 & 0.03 \\
\hline & Post-treatment & $188.10 \pm 4.06^{\mathrm{a}}$ & $162.13 \pm 5.30^{b}$ & $170.78 \pm 6.20^{b}$ & 0.001 & 0.40 & 0.67 \\
\hline \multirow{2}{*}{ Triglycerides (mg/dL) } & Treatment & $42.40 \pm 1.02$ & $39.87 \pm 0.77$ & $41.94 \pm 0.77$ & 0.08 & 0.04 & 0.37 \\
\hline & Post-treatment & $42.70 \pm 1.28$ & $44.00 \pm 1.26$ & $42.29 \pm 1.14$ & 0.59 & 0.52 & 0.28 \\
\hline \multirow{2}{*}{ Urea-N (mg/dL) } & Treatment & $34.97 \pm 0.66$ & $33.52 \pm 0.66$ & $33.88 \pm 0.68$ & 0.21 & 0.001 & 0.48 \\
\hline & Post-treatment & $33.20 \pm 0.95$ & $33.62 \pm 0.92$ & $32.65 \pm 0.83$ & 0.75 & 0.93 & 0.22 \\
\hline \multirow{2}{*}{ Creatinine (mg/dL) } & Treatment & $2.78 \pm 0.09^{\mathrm{a}}$ & $2.22 \pm 0.20^{b}$ & $2.36 \pm 0.19^{b}$ & 0.001 & 0.001 & 0.001 \\
\hline & Post-treatment & $2.91 \pm 0.11$ & $3.10 \pm 0.14$ & $3.14 \pm 0.09$ & 0.25 & 0.04 & 0.06 \\
\hline \multirow{2}{*}{ Glucose (mg/dL) } & Treatment & $85.18 \pm 1.04$ & $84.20 \pm 0.94$ & $83.73 \pm 0.81$ & 0.54 & 0.40 & 0.90 \\
\hline & Post-treatment & $83.66 \pm 1.45$ & $83.14 \pm 1.50$ & $83.78 \pm 1.34$ & 0.94 & 0.65 & 0.22 \\
\hline
\end{tabular}

Means with different superscripts within the same row are significantly different $(p<0.05)$. EOB, essential oil blend; $\mathrm{T}$, treatment; $\mathrm{W}$, weeks; $\mathrm{T} \times \mathrm{W}$, treatment $\times$ weeks. $\mathrm{EOB}$, mixing equal proportions of clove, oregano and juniper $\mathrm{EOs} ; \mathrm{EOB}_{2.5}, 2.5 \mathrm{~g} / \mathrm{head} /$ day of $\mathrm{EOB} ; \mathrm{EOB}_{5.0}, 5.0 \mathrm{~g} / \mathrm{head} /$ day of $\mathrm{EOB}$. 


\section{Discussion}

\subsection{Dry Matter Intake and Feed Efficiency}

The improvement of animal performance is one of the main goals of ruminant nutrition, and the way to attain this could be fulfilled by modifying animal feed intake and eating behavior. Recently, EOs of several spices and herbs have been used as feed additives to promote animal growth and production [29-31]. However, there are conflicting results regarding the effect of EOs on feed intake in the ruminants that were reviewed. The effect of EOs on DMI of lactating cows in the present study showed a significant decrease with the dietary supplementation of EOB at the two doses ( 2.5 and $5.0 \mathrm{~g} / \mathrm{head} /$ day). In the same manner, DMI reduced in dairy cattle received EOB supplementation [36,44], sheep received eucalyptus [54], and beef cattle received a mixture of cinnamaldehyde and eugenol [55].

One possible explanation for the reduction in DMI is that EOs could possess an irritating odor and smell of the ration, which could be related to less palatability of the animal diet. In contrast, the DMI was not affected by EOB supplementation in lactating cows [30,31,56], dairy goats [57], and sheep [37]. Moreover, juniper berry EO supplementation showed no effect on DMI in lactating cows [43] and lambs [58]. Additionally, adding oregano EO at a dose of $250 \mathrm{mg} / \mathrm{head} /$ day did not influence the feed intake of sheep [59]. Moreover, DMI was not affected by adding anise, clove, and juniper EOs to lactating Damascus goats at a dose of $2 \mathrm{~mL} /$ head/day compared with the control group [60]. However, the EOB (CRINA ruminant ${ }^{\circledR}$ ) supplementation increased DMI of cows [35]. Further, the EO supplementation increased DMI in fistulated nonlactating dairy cows [29]. Accordingly, several factors might lead to variations in the effect of EOs on DMI, such as EO sources and doses; diet types and interactions; and the adaptation of microbial populations in the rumen to the EOs [61].

The current results showed that supplementing $\mathrm{EOB}_{2.5}$ to the diet of lactating cows improved $(p \leq 0.001) \mathrm{FE}(1.31 \mathrm{MY} / \mathrm{kg}$ of DMI) compared with the control group (1.24 MY $/ \mathrm{kg}$ of DMI) by reducing DMI and increasing milk yield. The improvement of FE could be associated with an increasing trend of milk fat concentration relative to the control group. Similar to the present results, FE was higher than that of the control group by the addition of EOB in the diet of lactating cows $[36,62]$ and lactating ewes [41]. Furthermore, the FE of dairy cows was increased by the combination of EOs, which may be associated with changes in rumen fermentation when supplementing EOs [30,31,62]. In another note, the supplementing with EOB (CRINA ruminant ${ }^{\circledR}$ ) at a dose of $1.2 \mathrm{~g} /$ head/day did not affect FE in lactating cows [35].

\subsection{Milk Yield and Composition}

Milk yield, composition, and quality are important factors affecting the dairy farm's profitability. The current findings indicated that MY increased $(p \leq 0.02)$ in cows supplemented with EOB at doses of 2.5 and $5.0 \mathrm{~g} / \mathrm{head} /$ day during the treatment period. The results of the current study coincided with the previous findings, which found that the lactating cows fed diets supplemented with EOB tended to produce more milk than the control cows $[35,36]$. Furthermore, the supplementation with $1.5 \mathrm{~mL} /$ head/day of EOB increased $(p \leq 0.05) \mathrm{MY}$ in ewes when compared to the control group [63]. The supplementation with $500 \mathrm{mg} / \mathrm{kg}$ DM of commercial EOB increased $(p<0.001)$ cow's milk production [64]. The increase in MY with supplementation of EOB may be due to the higher ruminal total volatile fatty acids, the change in ruminal fermentation profile, and the reduction of methane production [3,11,42]. The mode of action of EOB on ruminal fermentation is throughout reducing the molar proportion of acetate and increasing the proportion of propionate, resulting in decreasing acetate-to-propionate ratio and less methane energy loss [11,62].

Furthermore, the increase in MY with supplementation of EOB could be due to an increase in endocrine stimulation of the animals [65], such as growth hormones, which promotes milk production by elevating the rate of change of nutrients from the body to the mammary gland, and glucocorticoids render for the start and maintenance of lactation [66]. Moreover, EOs components such as eugenol (the major constituent of clove EO), and thymol and carvacrol (the main constituents of oregano EO), 
and terpene hydrocarbons (the major component of juniper EO) have strong antioxidant properties [67]. Consequently, they have inhibitory activity against lipid peroxidation by interrupting chain reactions of free radical [67]. This results in in protecting and maintaining mammary secretory cell healthy, secretory activity, and the eject ability of alveoli through antioxidant effects [68]. An opposite trend, EOB supplementation had no significant effect on the MY of lactating dairy cows $[28,40,56]$. The reasons for the discrepancies between studies are difficult to explain but could be related to differences in dietary EOB inclusion levels, feed intake, diet composition, lactation stage, and the trial duration. More long-term studies are required to evaluate the effect of EOB supplementation on milk production in lactating dairy cows [44].

It is known that Holstein cows have the lowest fat and protein content, and they produce more milk. Therefore, they generally have a higher total yield of fat and protein than other breeds [69]. Moreover, the percentages of MY and milk composition are negatively correlated ( -0.3$)$ to the percentages of MY and fat [70]. The current findings showed that $\mathrm{EOB}_{2.5}$ supplementation in the dairy cow diet under the experimental conditions did not affect FCM and fat percentage. In the same line, the milk fat percentage of Holstein cows was not affected by the addition of EOB (CRINA ruminant ${ }^{\circledR}$ ) at a dose of $0.750 \mathrm{~g} /$ head/day [56], the mixture of equal proportions of cinnamaldehyde and eugenol at different levels [71], and $500 \mathrm{mg} / \mathrm{kg}$ DM of a commercial blend of cashew nut shell liquid and castor oil [64]. In contrast to the current findings, the milk fat percentage and milk fat yield were higher in Holstein cows supplemented with $1 \mathrm{~g} / \mathrm{head} /$ day of EOB [40]. Additionally, there were an increase in MY, milk fat, and FCM in dairy cows fed with $1.2 \mathrm{~g}$ of a commercial EOB [31].

The present results demonstrate that the percentage of protein was increased $(p \leq 0.03)$ with EOB inclusion at the higher dose in the dairy cow diet. In accordance, the milk protein of dairy cows was increased by supplementing EOB [56] or a commercial blend of cashew nut shell liquid and castor oil [64]. The increase in milk protein with EOs additives could be due to the improvement of ruminal microbial protein synthesis as a result of decreasing ruminal $\mathrm{NH}_{3}$ concentration [42]. However, contrary to the present findings, the milk protein was not affected by the addition of EOB at different levels to the diet of Holstein cows [35,44,71] or lactating ewes [41]. However, the addition of $1.2 \mathrm{~g} / \mathrm{head} / \mathrm{day}$ of EOB (CRINA ruminant ${ }^{\circledR}$ ) decreased the milk protein content by $0.15 \%$ units than the control group [36].

The milk lactose percentage was increased $(p \leq 0.03)$ in lactating cows supplemented with $\mathrm{EOB}_{5.0}$. In the same manner, there was a significant increase in milk lactose concentration with cows supplemented with $0.750 \mathrm{~g} / \mathrm{head} /$ day of EOB [56] or $500 \mathrm{mg} / \mathrm{kg}$ DM of a commercial blend of cashew nut shell liquid and castor oil [64], and ewes supplemented with $1.5 \mathrm{~mL} / \mathrm{head} /$ day of EOB [63]. The increase in the milk lactose may be due to a parallel increase in the amount of glucose transport and uptake by the mammary glands [72]. On the contrary, lactose concentration was not affected by supplementing a blend of cinnamaldehyde and garlic oils at a dose of $300 \mathrm{mg} / \mathrm{cow} / \mathrm{day}$ [28].

\subsection{Milk Total Bacterial Count and Somatic Cell Count}

Milk TBC and SCC play a key role in monitoring the milk quality, the degree of udder health, and the efficiency of management. The mammary glands synthesize milk from specialized cells. Therefore, milk is virtually sterile when secreted into the alveoli of the udder [73]. After this stage of milk production, some factors can generally cause microbial contamination of milk and increase milk TBC, such as internal and external udder environment, milk-handling surfaces, and storage equipment [74]. It is noteworthy that milk SCC of a healthy cow includes 75 to $85 \%$ leukocytes and 15 to $25 \%$ epithelial cells [75]. Udder health abnormalities are linked to a significant increase in milk SCC (rate of 5 to 20\%), and it can cause a reduction in MY [76]. The high milk SCC negatively affects not only MY but also milk composition and quality [77].

The present findings reveal that the means of milk TBC showed an insignificant reduction by 20.7 and $17.9 \%$ with $\mathrm{EOB}_{2.5}$ and $\mathrm{EOB}_{5.0}$, respectively, compared with the control group. The improvement of the microbial profile of milk was also enhanced during the post-treatment period. Moreover, the current results showed that the addition of $\mathrm{EOB}_{2.5}$ and $\mathrm{EOB}_{5.0}$ to the cow's diet caused an insignificant decrease 
of 20.6 and $9.9 \%$ in milk SCC, respectively, compared to the control group. Similar to the current results, the milk SSC of lactating cows was lower by dietary supplementation with EOB (CRINA ruminant $\left.{ }^{\circledR}\right)$ at a dose of $150 \mathrm{mg} / \mathrm{kg}$ of the concentrated feed [41] or blend of cinnamaldehyde and garlic oil at a dose of $300 \mathrm{mg} / \mathrm{cow} /$ day [28]. The reduction in Milk TBC and SCC by the addition of $\mathrm{EOB}_{2.5}$ and $\mathrm{EOB}_{5.0}$ to the cow's diet may be due to the antimicrobial effects of EOs [11]. In the same vein, the phytogenic additives as EOs have antimicrobial, antiviral, anthelmintic, and coccidiostat activities [65]. Essential oils show broad-spectrum inhibitory activities against several bacteria [78,79] via different modes of action, including the lipophilic characteristic of EOs causing it to be easily permeable through the cell wall and cell membrane. Besides, the interaction of EOs constituents with polysaccharides, fatty acids, and phospholipids leads to the disorder of membrane integrity, loss of the cell contents, confusion in proton pump activity, and thus cell death [80]. Furthermore, the denaturation of cellular proteins is an important mechanism of action of EOs [79,81]. Moreover, phenolic hydroxyl group, which was found in EOs, accrues in the lipid phase of the membrane which results in the expansion of the phospholipids bilayer and increasing spaces and modulate ion infiltration [82].

\subsection{Hematological Parameters and Blood Metabolites}

Regarding the physiological performance of lactating cows fed diets supplemented with EOB in the present study, the results did not show any significant changes in RBCs, WBCs counts, and $\mathrm{Hb}$ level with different EOB supplemented groups. In the same line, yearling steers and growing beef heifers fed diets supplemented with cinnamaldehyde did not affect plasma haptoglobin level and WBCs [83,84]. Additionally, lactating cows fed diets supplemented with juniper or garlic oils did not express any changes in WBCs count and differential leukocyte count [43].

Meanwhile, the EOB supplementation exerted significant effects on blood metabolites in the present study. Serum total protein, albumin, and globulin concentrations were increased with the dietary supplementation of EOB in the current study. In accordance, the dietary supplementation of different essential oils (anise, clove, and juniper; $2 \mathrm{~mL} \mathrm{EO/head/day)} \mathrm{and} \mathrm{EOB} \mathrm{significantly} \mathrm{increased}$ total protein, albumin, and globulin [60,63]. However, sheep fed garlic EO or lambs fed an EOB (thymol, carvacrol, eugenol, limonene, and cinnamaldehyde) supplemented diet did not affect plasma total protein and albumin $[38,85]$. The improvement of serum protein of animals fed EOB in the present study could be due to the EOs content of phytochemicals, whereas, the phytogenic additives as EOs have immune stimulation, and anti-inflammatory and antioxidative activities [65].

Moreover, serum total cholesterol was significantly decreased in cows fed the EOB supplemented diet in the present study. In the same sense, early lactating cows fed EOB (containing cinnamaldehyde and diallyl disulphide) supplemented diet had lower cholesterol concentration even during heat stress [86]. Additionally, EOs (anise, clove, and juniper EOs; $2 \mathrm{~mL} /$ head/day) supplementation decreased cholesterol in lactating Damascus goats [60]. The change of cholesterol level in the present study could be attributed to the effect of EOs supplementation on feed intake, rumen fermentation and increasing propionate, butyrate, and valerate, which could slow down the triacylglycerol and cholesterol synthesis in hepatocytes and may change the lipid profile of blood [87].

The present findings revealed serum urea- $\mathrm{N}$ concentration was not affected in lactating cows fed EOB supplemented diets compared to the control group. In contrast, serum urea-N concentration decreased in lambs fed a supplemented diet with cinnamaldehyde [88]. EOs (anise, clove, juniper, Allicin, zingiberene, and citral) decreased blood urea- $\mathrm{N}$ concentration in lactating Damascus goats and a non-lactating dairy cow, respectively $[29,60]$. However, the current results indicated that the serum creatinine concentration was decreased $(p \leq 0.001)$ with both doses of EOB supplementation compared to the control. In the same manner, the EOB (carvacrol, cinnamaldehyde, and capsaicin) supplementation decreased serum creatinine level in calves [89].

The glucose level did not differ significantly among different studied treatments in the present study. In agreement, the glucose level of early lactating dairy cows fed EOB (Crina ${ }^{\circledR}$ ruminant) 
supplemented diets was not affected by treatment. Additionally, Damascus goats and growing lambs fed different EO or EOB did not show significant alteration in glucose levels [7,38].

\section{Conclusions}

Based on the results, it can be concluded that the dietary supplementation with 2.5 and $5 \mathrm{~g} / \mathrm{head} / \mathrm{day}$ of essential oil blend (EOB, mixed equal proportions of clove, oregano, and juniper essential oils in the laboratory) for early lactating cows improved milk yield, feed efficiency, some parameters of milk composition, and animal hemato-biochemical status. In addition, EOB supplementation reduced milk total bacterial and milk somatic cell counts. Furthermore, it is better to supplement lower doses of EOB in the diets of lactating cows than higher doses, suggesting that lower doses may not inhibit rumen microbial populations. Moreover, the post-treatment effect of EOB supplementation of dairy cows had no clear effect, since some investigated parameters maintained their level during the post-treatment period while others were retarded. Therefore, the addition of EOB in livestock diets has beneficial effects on lactating animal performance and could be used as sustainable natural alternative to antibiotics.

Author Contributions: Conceptualization, S.B.A.-S., S.A.M., M.H.A., S.M.Z., and S.M.A.S.; data curation, T.M.A.; formal analysis, A.T.M.; funding acquisition, S.B.A.-S. and T.M.A.; investigation, S.A.M. and A.T.M.; methodology, S.A.M. and S.M.A.S.; project administration, M.H.A., S.M.Z., and S.M.A.S.; resources, S.B.A.-S., S.A.M., M.H.A., S.M.Z., and S.M.A.S.; software, A.T.M.; supervision, M.H.A., S.M.Z. and S.M.A.S.; validation, S.B.A.-S. and A.T.M.; visualization, A.T.M. and T.M.A.; writing-original draft, S.A.M., S.B.A.-S.; writing-review and editing, S.B.A., S.B.A.-S., A.T.M., and S.M.A.S. All authors have read and agreed to the published version of the manuscript.

Funding: The authors extend their appreciation to the Deputyship for Research and Innovation, Ministry of Education in Saudi Arabia for funding this research work through the project number IFT20019. The fund supported the publication of this work.

Conflicts of Interest: The authors declare no conflict of interest.

\section{References}

1. Martinez, S.; Madrid, J.; Hernandez, F.; Megias, M.; Sotomayor, J.; Jordan, M. Effect of thyme essential oils (Thymus hyemalis and Thymus zygis) and monensin on in vitro ruminal degradation and volatile fatty acid production. J. Agric. Food Chem. 2006, 54, 6598-6602. [CrossRef] [PubMed]

2. Jayalakshmi, K.; Paramasivam, M.; Sasikala, M.; Tamilam, T.; Sumithra, A. Review on antibiotic residues in animal products and its impact on environments and human health. J. Entomol. Zool. Stud. 2017, 5, 1446-1451.

3. Benchaar, C.; Calsamiglia, S.; Chaves, A.V.; Fraser, G.R.; Colombatto, D.; McAllister, T.A.; Beauchemin, K.A. A review of plant-derived essential oils in ruminant nutrition and production. Anim. Feed Sci. Technol. 2008, 145, 209-228. [CrossRef]

4. Nagpal, R.; Shrivastava, B.; Kumar, N.; Dhewa, T.; Sahay, H. Microbial Feed Additives. In Rumen Microbiology: From Evolution to Revolution; Springer: New Delhi, India, 2015; pp. 161-175.

5. Carro, M.; Ungerfeld, E. Utilization of Organic Acids to Manipulate Ruminal Fermentation and Improve Ruminant Productivity. In Rumen Microbiology: From Evolution to Revolution; Springer: New Delhi, India, 2015; pp. 177-197.

6. Sallam, S.M.A.; Allam, A.M.; Najadi, S.A. Comparison of two products of direct-fed microbial supplementation on the nutrient utilization and ruminal fermentation in sheep. J. Agric. Sci. 2014, 6, 159. [CrossRef]

7. Morsy, A.S.; Abdalla, A.L.; Soltan, Y.A.; Sallam, S.M.; El-Azrak, K.E.D.M.; Louvandini, H.; Alencar, S.M. Effect of Brazilian red propolis administration on hematological, biochemical variables and parasitic response of Santa Inês ewes during and after flushing period. Trop. Anim. Health Prod. 2013, 45, 1609-1618. [CrossRef] [PubMed]

8. Sallam, S.M.; Bueno, I.C.; Nasser, M.E.; Abdalla, A.L. Effect of eucalyptus (Eucalyptus citriodora) fresh or residue leaves on methane emission in vitro. Ital. J. Anim. Sci. 2010, 9, e58.

9. Deyno, S.; Mtewa, A.G.; Abebe, A.; Hymete, A.; Makonnen, E.; Bazira, J.; Alele, P.E. Essential oils as topical anti-infective agents: A systematic review and meta-analysis. Complement. Ther. Med. 2019, 47, 102224. [CrossRef] 
10. Herago, T.; Agonafir, A. Growth promoters in cattle. Adv. Biol. Res. 2017, 11, 24-34.

11. Calsamiglia, S.; Busquet, M.; Cardozo, P.; Castillejos, L.; Ferret, A. Invited review: Essential oils as modifiers of rumen microbial fermentation. J. Dairy Sci. 2007, 90, 2580-2595. [CrossRef]

12. Greathead, H. Plants and plant extracts for improving animal productivity. Proc. Nutr. Soc. 2003, 62, 279-290. [CrossRef]

13. Aali, E.; Mahmoudi, R.; Kazeminia, M.; Hazrati, R.; Azarpey, F. Essential oils as natural medicinal substances. Tehran Univ. Med. J. 2017, 75, 480-489.

14. Mancianti, F.; Ebani, V.V. Biological activity of essential oils. Molecules 2020, 25, 678-681. [CrossRef] [PubMed]

15. Xu, J.G.; Liu, T.; Hu, Q.P.; Cao, X.M. Chemical composition, antibacterial properties and mechanism of action of essential oil from clove buds against Staphylococcus aureus. Molecules 2016, 21, 1194. [CrossRef] [PubMed]

16. Radünz, M.; da Trindade, M.L.M.; Camargo, T.M.; Radünz, A.L.; Borges, C.D.; Gandra, E.A.; Helbig, E. Antimicrobial and antioxidant activity of unencapsulated and encapsulated clove (Syzygium aromaticum, L.) essential oil. Food Chem. 2019, 276, 180-186. [CrossRef]

17. Selles, S.M.A.; Kouidri, M.; Belhamiti, B.T.; Amrane, A.A. Chemical composition, in-vitro antibacterial and antioxidant activities of Syzygium aromaticum essential oil. J. Food Meas. Charact. 2020, 14, 2352-2358. [CrossRef]

18. Dutra, T.V.; Castro, J.C.; Menezes, J.L.; Ramos, T.R.; do Prado, I.N.; Junior, M.M.; Mikcha, J.M.G.; de Abreu Filho, B.A. Bioactivity of oregano (Origanum vulgare) essential oil against Alicyclobacillus spp. Ind. Crops Prod. 2019, 129, 345-349. [CrossRef]

19. Olijhoek, D.; Hellwing, A.L.F.; Grevsen, K.; Haveman, L.; Chowdhury, M.R.; Løvendahl, P.; Weisbjerg, M.R.; Noel, S.J.; Højberg, O.; Wiking, L. Effect of dried oregano (Origanum vulgare L.) plant material in feed on methane production, rumen fermentation, nutrient digestibility, and milk fatty acid composition in dairy cows. J. Dairy Sci. 2019, 102, 9902-9918. [CrossRef] [PubMed]

20. Roofchaee, A.; Irani, M.; Ebrahimzadeh, M.A.; Akbari, M.R. Effect of dietary oregano (Origanum vulgare L.) essential oil on growth performance, cecal microflora and serum antioxidant activity of broiler chickens. Afr. J. Biotechnol. 2011, 10, 6177-6183.

21. Davidson, P.M.; Naidu, A.S. Phyto-phenols. In Natural Food Antimicrobial Systems; Naidu, A.S., Ed.; CRC Press: Boca Raton, FL, USA, 2000; pp. 265-294.

22. Cui, H.; Zhang, C.; Li, C.; Lin, L. Antibacterial mechanism of oregano essential oil. Ind. Crops Prod. 2019, 139, 111498. [CrossRef]

23. Höferl, M.; Stoilova, I.; Schmidt, E.; Wanner, J.; Jirovetz, L.; Trifonova, D.; Krastev, L.; Krastanov, A. Chemical composition and antioxidant properties of juniper berry (Juniperus communis L.) essential oil. Action of the essential oil on the antioxidant protection of Saccharomyces cerevisiae model organism. Antioxidants 2014, 3, 81-98. [CrossRef]

24. Orav, A.; Kailas, T.; Müürisepp, M. Chemical investigation of the essential oil from berries and needles of common juniper (Juniperus communis L.) growing wild in Estonia. Nat. Prod. Res. 2010, 24, 1789-1799. [CrossRef]

25. Zheljazkov, V.D.; Semerdjieva, I.B.; Dincheva, I.; Kacaniova, M.; Astatkie, T.; Radoukova, T.; Schlegel, V. Antimicrobial and antioxidant activity of Juniper galbuli essential oil constituents eluted at different times. Ind. Crops Prod. 2017, 109, 529-537. [CrossRef]

26. Radoukova, T.; Zheljazkov, V.; Semerdjieva, I.; Dincheva, I.; Stoyanova, A.; Kačániová, M.; Marković, T.; Radanović, D.; Astatkie, T.; Salamon, I. Differences in essential oil yield, composition, and bioactivity of three juniper species from Eastern Europe. Ind. Crops Prod. 2018, 124, 643-652. [CrossRef]

27. Benchaar, C.; Hristov, A.N.; Greathead, H. Essential Oils as Feed Additives in Ruminant Nutrition. In Phytogenics in Animal Nutrition; Steiner, T., Ed.; Nottingham University Press: Nottingham, UK, 2009; pp. 111-146.

28. Blanch, M.; Carro, M.; Ranilla, M.J.; Viso, A.; Vázquez-Añón, M.; Bach, A. Influence of a mixture of cinnamaldehyde and garlic oil on rumen fermentation, feeding behavior and performance of lactating dairy cows. Anim. Feed Sci. Technol. 2016, 219, 313-323. [CrossRef]

29. Suksombat, W.; Nanon, A.; Meeprom, C.; Lounglawan, P. Feed degradability, rumen fermentation and blood metabolites in response to essential oil addition to fistulated non-lactating dairy cow diets. Anim. Sci. J. 2017, 88, 1346-1351. [CrossRef] 
30. Elcoso, G.; Zweifel, B.; Bach, A. Effects of a blend of essential oils on milk yield and feed efficiency of lactating dairy cows. Appl. Anim. Sci. 2019, 35, 304-311. [CrossRef]

31. Braun, H.S.; Schrapers, K.T.; Mahlkow-Nerge, K.; Stumpff, F.; Rosendahl, J. Dietary supplementation of essential oils in dairy cows: Evidence for stimulatory effects on nutrient absorption. Animal 2019, 13, 518-523. [CrossRef]

32. Spanghero, M.; Zanfi, C.; Fabbro, E.; Scicutella, N.; Camellini, C. Effects of a blend of essential oils on some end products of in vitro rumen fermentation. Anim. Feed Sci. Technol. 2008, 145, 364-374. [CrossRef]

33. Castillejos, L.; Calsamiglia, S.; Ferret, A.; Losa, R. Effects of a specific blend of essential oil compounds and the type of diet on rumen microbial fermentation and nutrient flow from a continuous culture system. Anim. Feed Sci. Technol. 2005, 119, 29-41. [CrossRef]

34. Castillejos, L.; Calsamiglia, S.; Ferret, A.; Losa, R. Effects of dose and adaptation time of a specific blend of essential oil compounds on rumen fermentation. Anim. Feed Sci. Technol. 2007, 132, 186-201. [CrossRef]

35. Kung, L.; Williams, P.; Schmidt, R.; Hu, W. A blend of essential plant oils used as an additive to alter silage fermentation or used as a feed additive for lactating dairy cows. J. Dairy Sci. 2008, 91, 4793-4800. [CrossRef] [PubMed]

36. Tassoul, M.; Shaver, R. Effect of a mixture of supplemental dietary plant essential oils on performance of periparturient and early lactation dairy cows. J. Dairy Sci. 2009, 92, 1734-1740. [CrossRef]

37. Ahmed, M.G.; El-Zarkouny, S.Z.; El-Shazly, K.A.; Sallam, S.M.A. Impact of essential oils blend on methane emission, rumen fermentation characteristics and nutrient digestibility in Barki sheep. J. Agric. Sci. 2014, 6, 144-156. [CrossRef]

38. Malekkhahi, M.; Tahmasbi, A.M.; Naserian, A.A.; Danesh Mesgaran, M.; Kleen, J.; Parand, A. Effects of essential oils, yeast culture and malate on rumen fermentation, blood metabolites, growth performance and nutrient digestibility of Baluchi lambs fed high-concentrate diets. J. Anim. Physiol. Anim. Nutr. 2015, 99, 221-229. [CrossRef] [PubMed]

39. Benchaar, C.; Lettat, A.; Hassanat, F.; Yang, W.; Forster, R.; Petit, H.; Chouinard, P. Eugenol for dairy cows fed low or high concentrate diets: Effects on digestion, ruminal fermentation characteristics, rumen microbial populations and milk fatty acid profile. Anim. Feed Sci. Technol. 2012, 178, 139-150. [CrossRef]

40. Santos, M.; Robinson, P.; Williams, P.; Losa, R. Effects of addition of an essential oil complex to the diet of lactating dairy cows on whole tract digestion of nutrients and productive performance. Anim. Feed Sci. Technol. 2010, 157, 64-71. [CrossRef]

41. Giannenas, I.; Skoufos, J.; Giannakopoulos, C.; Wiemann, M.; Gortzi, O.; Lalas, S.; Kyriazakis, I. Effects of essential oils on milk production, milk composition, and rumen microbiota in Chios dairy ewes. J. Dairy Sci. 2011, 94, 5569-5577. [CrossRef] [PubMed]

42. Morshedy, S.A. Effect of Blending Volatile Oil Mixtures on Rumen Fermentation, Methane Emission and Milk Production in Ruminants; University of Alexandria: Alexandria, Egypt, 2015.

43. Yang, W.; Benchaar, C.; Ametaj, B.; Chaves, A.; He, M.; McAllister, T. Effects of garlic and juniper berry essential oils on ruminal fermentation and on the site and extent of digestion in lactating cows. J. Dairy Sci. 2007, 90, 5671-5681. [CrossRef]

44. Benchaar, C.; Petit, H.; Berthiaume, R.; Whyte, T.; Chouinard, P. Effects of addition of essential oils and monensin premix on digestion, ruminal fermentation, milk production, and milk composition in dairy cows. J. Dairy Sci. 2006, 89, 4352-4364. [CrossRef]

45. NRC. National Research Council Nutrient Requirements of Dairy Cattle, 7th ed.; National Academy Press: Washington, DC, USA, 2001.

46. AOAC. Association of Official Analytical Chemists Official Method of Analysis; AOAC International: Gaithersburg, MD, USA, 2006.

47. Van Soest, P.J.; Robertson, J.; Lewis, B. Methods for dietary fiber, neutral detergent fiber, and nonstarch polysaccharides in relation to animal nutrition. J. Dairy Sci. 1991, 74, 3583-3597. [CrossRef]

48. Van Soest, P.J. Collaborative study of acid-detergent fiber and lignin. J. Assoc. Off. Anal. Chem. 1973, 56, 781-784. [CrossRef]

49. Gaines, W.L.; Davidson, F.A. Relation between Percentage Fat Content and Yield of Milk: Correction of Milk Yield for Fat Content; Bulletin No. 245; University of Illinois, Agricultural Experiment Station, Urbana-Champaign Campus: Champaign, IL, USA, 1923. 
50. Tyrrell, H.; Reid, J. Prediction of the energy value of cow's milk 1, 2. J. Dairy Sci. 1965, 48, 1215-1223. [CrossRef]

51. Houghtby, G.; Maturin, L.; Koenig, E. Microbiological Count Methods. In Standard Methods for the Examination of Dairy Products; Marshal, T.R., Ed.; American Public Health Association: Washington, DC, USA, 1992; pp. $213-246$.

52. SAS Institute Inc. SAS/STAT User's Guide: Version 9, 2nd ed.; SAS Institute Inc.: Cary, NC, USA, 2008.

53. Duncan, D.B. Multiple range and $F$ tests. Biometric 1955, 11, 1-42. [CrossRef]

54. Sallam, S.; Bueno, I.; Brigide, P.; Godoy, P.; Vitti, D.; Abdalla, A. Investigation of potential new opportunities for plant extracts on rumen microbial fermentation in vitro. Nutr. Foraging Ecol. Sheep Goats 2009, 303, 255-260.

55. Cardozo, P.W.; Calsamiglia, S.; Ferret, A.; Kamel, C. Effects of alfalfa extract, anise, capsicum, and a mixture of cinnamaldehyde and eugenol on ruminal fermentation and protein degradation in beef heifers fed a high-concentrate diet. J. Anim. Sci. 2006, 84, 2801. [CrossRef] [PubMed]

56. Benchaar, C.; Petit, H.; Berthiaume, R.; Ouellet, D.; Chiquette, J.; Chouinard, P. Effects of essential oils on digestion, ruminal fermentation, rumen microbial populations, milk production, and milk composition in dairy cows fed alfalfa silage or corn silage. J. Dairy Sci. 2007, 90, 886-897. [CrossRef]

57. Malecky, M.; Broudiscou, L.; Schmidely, P. Effects of two levels of monoterpene blend on rumen fermentation, terpene and nutrient flows in the duodenum and milk production in dairy goats. Anim. Feed Sci. Technol. 2009, 154, 24-35. [CrossRef]

58. Chaves, A.V.; Stanford, K.; Dugan, M.E.R.; Gibson, L.L.; McAllister, T.A.; Van Herk, F.; Benchaar, C. Effects of cinnamaldehyde, garlic and juniper berry essential oils on rumen fermentation, blood metabolites, growth performance, and carcass characteristics of growing lambs. Livest. Sci. 2008, 117, 215-224. [CrossRef]

59. Wang, C.; Wang, S.; Zhou, H. Influences of flavomycin, ropadiar, and saponin on nutrient digestibility, rumen fermentation, and methane emission from sheep. Anim. Feed Sci. Technol. 2009, 148, 157-166. [CrossRef]

60. Morsy, T.; Kholif, S.; Matloup, O.; Abdo, M.; El-Shafie, M. Impact of anise, clove and juniper oils as feed additives on the productive performance of lactating goats. Int. J. Dairy Sci. 2012, 7, 20-28.

61. Geraci, J.I.; Garciarena, A.D.; Gagliostro, G.A.; Beauchemin, K.A.; Colombatto, D. Plant extracts containing cinnamaldehyde, eugenol and capsicum oleoresin added to feedlot cattle diets: Ruminal environment, short term intake pattern and animal performance. Anim. Feed Sci. Technol. 2012, 176, 123-130. [CrossRef]

62. Da Silva, R.B.; Pereira, M.N.; de Araujo, R.C.; Silva, W.d.R.; Pereira, R.A.N. A blend of essential oils improved feed efficiency and affected ruminal and systemic variables of dairy cows. Transl. Anim. Sci. 2020, 4, 182-193. [CrossRef] [PubMed]

63. El-Azrak, K.M.K. Effect of Essential Oils Administration on Some Productive and Reproductive Traits in Sheep; University of Alexandria: Alexandria, Egypt, 2012.

64. De Jesus, E.F.; Del Valle, T.; Calomeni, G.; Silva, T.; Takiya, C.; Vendramini, T.; Paiva, P.; Silva, G.; Netto, A.; Rennó, F. Influence of a blend of functional oils or monensin on nutrient intake and digestibility, ruminal fermentation and milk production of dairy cows. Anim. Feed Sci. Technol. 2016, 219, 59-67. [CrossRef]

65. Kırkpınar, F.; Ünlü, H.B.; Özdemir, G. Effects of oregano and garlic essential oils on performance, carcase, organ and blood characteristics and intestinal microflora of broilers. Livest. Sci. 2011, 137, 219-225. [CrossRef]

66. Svennersten-Sjaunja, K.; Olsson, K. Endocrinology of milk production. Domest. Anim. Endocrinol. 2005, 29, 241-258. [CrossRef]

67. Miguel, M.G. Antioxidant and anti-inflammatory activities of essential oils: A short review. Molecules 2010, 15, 9252-9287. [CrossRef]

68. Harding, F. World Milk Production. In Milk Quality; Springer: Boston, MA, USA, 1995; pp. 1-2.

69. Heinrichs, J.; Jones, C.; Bailey, K. Milk components: Understanding the Causes and Importance of Milk Fat and Protein Variation in Your Dairy Herd. In Dairy and Animal Science Fact Sheet; Department of Dairy and Animal Science, The Pennsylvania State University: State College, PA, USA, 1997; Volume 5, pp. 1e-8e.

70. Gaunt, S. Genetic variation in the yields and contents of milk constituents (quantitative differences; milk proteins, lactose, ash, non-fat solids; dairy cows breeds; Ayrshire; Brown Swiss; Guernsey; Holstein Friesian; Jersey). Bull. Int. Dairy Fed. Belgium 1980, 125, 73-82.

71. Flores, A.J.; Garciarena, A.D.; Vieyra, J.M.H.; Beauchemin, K.A.; Colombatto, D. Effects of specific essential oil compounds on the ruminal environment, milk production and milk composition of lactating dairy cows at pasture. Anim. Feed Sci. Technol. 2013, 186, 20-26. [CrossRef]

72. Plaizier, J.; Khafipour, E.; Li, S.; Gozho, G.; Krause, D. Subacute ruminal acidosis (SARA), endotoxins and health consequences. Anim. Feed Sci. Technol. 2012, 172, 9-21. [CrossRef] 
73. Tolle, A. The Microflora of the Udder. In Factors Influencing the Bacteriological Quality of Raw Milk; Bulletin International Dairy Federation: Brussels, Belgium, 1980; p. 4.

74. Bramley, A.; McKinnon, C. The Microbiology of Raw Milk. In Dairy Microbiology the Microbiology of Milk, 2nd ed.; Robinson, R.K., Ed.; Elsevier Science: London, UK, 1990; Volume 1, pp. 163-208.

75. Barrett, D. High somatic cell counts-a persistent problem. Ir. Vet. J. 2002, 55, 173.

76. Juozaitiene, V.; Juozaitis, A.; Micikeviciene, R. Relationship between somatic cell count and milk production or morphological traits of udder in Black-and-White cows. Turk. J. Vet. Anim. Sci. 2006, 30, 47-51.

77. Cinar, M.; Serbester, U.; Ceyhan, A.; Gorgulu, M. Effect of somatic cell count on milk yield and composition of first and second lactation dairy cows. Ital. J. Anim. Sci. 2015, 14, 3646. [CrossRef]

78. Teixeira, B.; Marques, A.; Ramos, C.; Neng, N.R.; Nogueira, J.M.; Saraiva, J.A.; Nunes, M.L. Chemical composition and antibacterial and antioxidant properties of commercial essential oils. Ind. Crops Prod. 2013, 43, 587-595. [CrossRef]

79. Morsy, N.F.S. Chemical structure, quality indices and bioactivity of essential oil constituents. Act. Ingred. Aromat. Med. Plants 2017, 175-206.

80. Saad, N.Y.; Muller, C.D.; Lobstein, A. Major bioactivities and mechanism of action of essential oils and their components. Flavour Fragrance J. 2013, 28, 269-279. [CrossRef]

81. Bakkali, F.; Averbeck, S.; Averbeck, D.; Idaomar, M. Biological effects of essential oils-A review. Food Chem. Toxicol. 2008, 46, 446-475. [CrossRef]

82. Ultee, A.; Bennik, M.; Moezelaar, R. The phenolic hydroxyl group of carvacrol is essential for action against the food-borne pathogen Bacillus cereus. Appl. Environ. Microbiol. 2002, 68, 1561-1568. [CrossRef]

83. Yang, W.; Ametaj, B.; Benchaar, C.; He, M.; Beauchemin, K. Cinnamaldehyde in feedlot cattle diets: Intake, growth performance, carcass characteristics, and blood metabolites. J. Anim. Sci. 2010, 88, 1082-1092. [CrossRef]

84. Yang, W.; Ametaj, B.; Benchaar, C.; Beauchemin, K. Dose response to cinnamaldehyde supplementation in growing beef heifers: Ruminal and intestinal digestion. J. Anim. Sci. 2010, 88, 680-688. [CrossRef]

85. Anassori, E.; Dalir-Naghadeh, B.; Pirmohammadi, R.; Hadian, M. Changes in blood profile in sheep receiving raw garlic, garlic oil or monensin. J. Anim. Physiol. Anim. Nutr. 2015, 99, 114-122. [CrossRef]

86. Serbester, U.; Çinar, M.; Ceyhan, A.; Erdem, H.; Görgülü, M.; Kutlu, H.; Çelik, L.; Yücelt, Ö.; Cardoza, P. Effect of essential oil combination on performance, milk composition, blood parameters and pregnancy rate in early lactating dairy cows during heat exposure. J. Anim. Plant Sci. 2012, 22, 556-563.

87. Kowalik, B.; Skomial, J.; Pajak, J.J.; Taciak, M.; Majewska, M.; Belzecki, G. Population of ciliates, rumen fermentation indicators and biochemical parameters of blood serum in heifers fed diets supplemented with yeast(Saccharomyces cerevisiae) preparation. Anim. Sci. Pap. Rep. 2012, 30, 329-338.

88. Chaves, A.; Dugan, M.; Stanford, K.; Gibson, L.; Bystrom, J.; McAllister, T.; Van Herk, F.; Benchaar, C. A dose-response of cinnamaldehyde supplementation on intake, ruminal fermentation, blood metabolites, growth performance, and carcass characteristics of growing lambs. Livest. Sci. 2011, 141, 213-220. [CrossRef]

89. Castillo, C.; Benedito, J.L.; Vázquez, P.; Pereira, V.; Méndez, J.; Sotillo, J.; Hernández, J. Effects of supplementation with plant extract product containing carvacrol, cinnamaldehyde and capsaicin on serum metabolites and enzymes during the finishing phase of feedlot-fed bull calves. Anim. Feed Sci. Technol. 2012, 171, 246-250. [CrossRef]

Publisher's Note: MDPI stays neutral with regard to jurisdictional claims in published maps and institutional affiliations.

(C) 2020 by the authors. Licensee MDPI, Basel, Switzerland. This article is an open access article distributed under the terms and conditions of the Creative Commons Attribution (CC BY) license (http://creativecommons.org/licenses/by/4.0/). 